\title{
$\int_{18}$ \\ METALURG \\ Majalah Ilmu dan Teknologi \\ p-ISSN 0126-3I88 | e-ISSN 2443-3926 \\ www.ejurnalmaterialmetalurgi.com

\section{THE EFFECT OF VARIATIONS IN ELECTROLYTE TEMPERATURE AND CURRENT ON THE SYNTHESIS OF MANGANESE DIOXIDE FROM Manganese Sulfate Precursors by Electrol ysis Method}

\author{
Rizta Febian Adi Endani ${ }^{a}$,*, Lia Andriyah ${ }^{b}$, Soesaptri Oediyani ${ }^{a}$, Latifa Hanum Lalasari ${ }^{b}$, \\ Tri Arini $^{b}$, Nadia Chrisayu Natasha ${ }^{b}$, Fariza Eka Yunitab, Ariyo Suharyanto ${ }^{b}$ \\ ${ }^{a}$ Metallurgical Engineering, Sultan Ageng Tirtayasa University \\ Jalan Jendral Sudirman Km.3, Cilegon, Indonesia 42434 \\ ${ }^{\mathrm{b}}$ Research Center for Metallurgy and Materials \\ Building 470, PUSPIPTEK Serpong Area, South Tangerang, Indonesia 15343 \\ *E-mail: febianrizta@gmail.com
}

Masuk tanggal : 28-07-2021, revisi tanggal : 02-09-2021, diterima untuk diterbitkan tanggal 09-09-2021

\begin{abstract}
Abstrak
Perkembangan ilmu dan teknologi dewasa ini dalam bidang elektronik, khususnya penyimpanan energi meningkatkan permintaan dalam penggunaan baterai sekunder litium. Pengembangan baterai litium difokuskan pada kapasitas penyimpanan energi dengan menggunakan mangan dioksida $\left(\mathrm{MnO}_{2}\right)$ sebagai bahan katoda baterai litium. Mangan dioksida dipilih sebagai bahan katoda baterai litium karena memiliki kapasitas penyimpanan yang tinggi yaitu sekitar $615 \mathrm{mAh} / \mathrm{g}$ dibandingkan dengan material lain seperti grafit yang memiliki kapasitas penyimpanan $372 \mathrm{mAh} / \mathrm{g}$. Sintesis $\mathrm{MnO}_{2}$ dilakukan dengan metode elektrolisis dari prekursor mangan sulfat $\left(\mathrm{MnSO}_{4}\right)$ yang diperoleh dari proses pelindian bijih mangan Kabupaten Trenggalek. Proses elektrolisis dilakukan selama 5 jam dengan menggunakan variasi temperatur elektrolit $30,40,50$ dan $60^{\circ} \mathrm{C}$ serta variasi arus 2, 3, 4 dan $5 \mathrm{~A}$ untuk mengetahui pengaruh temperatur elektrolit dan arus terhadap perolehan massa, polimorfi struktur dan morfologi $\mathrm{MnO}_{2}$ yang terbentuk. Perolehan massa tertinggi diperoleh pada penggunaan temperatur elektrolit $60{ }^{\circ} \mathrm{C}$ dan arus 5 A yaitu sebesar 11,4 gram. Hasil karakterisasi $\mathrm{MnO}_{2}$ dengan menggunakan XRF (x-ray fluorescence) Thermo type ARL 9900 menunjukkan kadar mangan dioksida sebesar 85,472\% dan hasil analisa dengan menggunakan XRD ( $x$-ray diffraction) Shimadzu type 7000 diperoleh polimorfi struktur senyawa $\mathrm{MnO}_{2}$ yang terbentuk adalah polimorfi $\alpha-\mathrm{MnO}_{2}$. Citra SEM (scanning electron microscope) menunjukkan bahwa partikel $\mathrm{MnO}_{2}$ memiliki bentuk bulat berduri dan cenderung beraglomerasi dengan nilai diameter partikel berkisar antara $50-70 \mathrm{~nm}$.
\end{abstract}

Kata Kunci: Elektrolisis, $\mathrm{MnO}_{2}, \mathrm{MnSO}_{4}$, temperatur elektrolit, arus

\begin{abstract}
The advancement of science and technology in the field of electronics, particularly in the field of energy storage, is increasing the demand for the use of lithium secondary batteries. The use of manganese dioxide $\left(\mathrm{MnO}_{2}\right)$ as a lithium battery cathode material is focusing the development of lithium batteries on energy storage capacity. Manganese dioxide was chosen as the cathode material for lithium batteries because it has a high storage capacity of about $615 \mathrm{mAh} / \mathrm{g}$ compared to other materials such as graphite which has a storage capacity of $372 \mathrm{mAh} / \mathrm{g} . \mathrm{MnO}_{2}$ was synthesized by the electrolysis method from manganese sulfate $\left(\mathrm{MnSO}_{4}\right)$ precursor which was obtained from the Trenggalek manganese ore leaching process. The electrolysis process was carried out for 5 hours using variations in electrolyte temperature of 30 , 40,50 , and $60^{\circ} \mathrm{C}$ as well as variations in a current of 2, 3, 4, and $5 \mathrm{~A}$ to determine the effect of electrolyte temperature and current on mass gain, structural polymorphy, and morphology of $\mathrm{MnO}_{2}$ formed. The highest mass gain was obtained at the use of an electrolyte temperature of $60^{\circ} \mathrm{C}$ and a current of $5 \mathrm{~A}$, which was 11.4 grams. The characterization of $\mathrm{MnO}_{2}$ using XRF (x-ray fluorescence) Thermo type ARL 9900 revealed manganese dioxide levels of 85.472\%, and the analysis using XRD (x-ray diffraction) Shimadzu type 7000 revealed that the polymorphy structure of the $\mathrm{MnO}_{2}$ compound formed was $\alpha-\mathrm{MnO}_{2}$ polymorphy. The $\mathrm{MnO}_{2}$ particles have a spiny round shape and tend to agglomerate, as shown by the SEM (scanning electron microscope) image, with particle diameter values ranging from 50 to $170 \mathrm{~nm}$.
\end{abstract}

Keywords: Electrolysis, $\mathrm{MnO}_{2}, \mathrm{MnSO}_{4}$, electrolyte temperature, current 


\section{INTRODUCTION}

Batteries have been the most widely developed electrical energy storage technology as science and technology have progressed, particularly in the field of electronics in energy storage. Lithium battery is a secondary battery that is widely developed today. Lithium batteries have advantages including high storage capacity, no memory effect, and can be recharged [1]. The development of lithium batteries is focused on increasing battery storage capacity and battery charging speed. One of the materials that are widely used as a lithium battery cathode is manganese dioxide $\left(\mathrm{MnO}_{2}\right)$. Based on data from the Geological Agency, Ministry of Energy and Mineral Resources, it is stated that manganese resources in Indonesia are about $60,893,820$ tons and total manganese reserves are $87,236,536$ tons [2]. With the manganese potential in Indonesia, the processing and utilization of manganese ore can be distinguished based on the manganese content in the ore. Manganese ore processing based on grade can be divided into two, pyrometallurgical and hydrometallurgical. Manganese ore with levels above $45 \%$ or commonly referred to as metallurgical grade is processed pyrometallurgical into ferromanganese metal as a ferroalloy for the manufacture of iron and steel. Meanwhile, manganese ores with levels below $45 \%$ are hydrometallurgically treated and used for the production of nonmetallurgical grades which are suitable for use in the dry battery industry as battery electrodes [3].

Manganese dioxide was chosen as the cathode material for lithium batteries because it has a high storage capacity of about $615 \mathrm{mAh} / \mathrm{g}$ [4]. Manganese dioxide is an oxide of manganese that can be crystalline or amorphous. The crystalline structure has a polymorphic crystal structure, such as $\beta-\mathrm{MnO}_{2}, \alpha-\mathrm{MnO}_{2}, \gamma-\mathrm{MnO}_{2}$ or $\delta-\mathrm{MnO}_{2}$. The polymorphic structure of $\mathrm{MnO}_{2}$ can possess a widely varying structural composition, and hence electrochemical activity [5]. Each of these crystalline structures has a tunnel structure with different sizes. $\beta-\mathrm{MnO}_{2}$ (pyrolusite), $\alpha-\mathrm{MnO}_{2}$ (ramsdellite), $\gamma-\mathrm{MnO}_{2}$ (nsutite) and $\delta-\mathrm{MnO}_{2}$ (vernadite) have tunnel structures $(1 \mathrm{x} 1)$, $(2 \times 2),(1 \times 1)(1 \times 2)$, and $(1 \times \infty)$ successively [6]. Among the various polymorphies of $\mathrm{MnO}_{2}$, such as $\beta-\mathrm{MnO}_{2}, \alpha-\mathrm{MnO}_{2}, \delta-\mathrm{MnO}_{2}$, and $\gamma-\mathrm{MnO}_{2}$, the polymorphic structure $\alpha-\mathrm{MnO}_{2}$ is much more active both chemically and electrochemically [7]. The polymorphic structure $\alpha-\mathrm{MnO}_{2}$ is the most suitable for battery applications and can be made chemically and electrochemically [8].

\section{Materials AND MethodS}

2 liters of $\mathrm{MnSO}_{4}$ were filtered for impurities before being poured into a $2000 \mathrm{ml}$ beaker. $5 \mathrm{ml}$ of $\mathrm{MnSO}_{4}$ solution was taken and diluted up to 100 times in a volumetric flask before being analyzed for elemental content using ICP-OES (inductively coupled plasmaoptical emission spectrometry). The anode was then wrapped in a screen mesh cloth and two graphite electrodes $\left(16 \times 5 \times 0.3 \mathrm{~cm}^{3}\right)$ were prepared. $\mathrm{MnSO}_{4}$ solution was electrolyzed for 5 hours with electrolyte temperature variations of $30,40,50$, and $60{ }^{\circ} \mathrm{C}$ and current variations of 2 , 3,4 , and $5 \mathrm{~A}$.

The $\mathrm{MnO}_{2}$ obtained was then dried in an oven for 2 hours and at a temperature of $110{ }^{\circ} \mathrm{C}$. Furthermore, the $\mathrm{MnO}_{2}$ formed was weighed using a digital balance and analyzed using XRF (x-ray fluorescence) Thermo type ARL 9900 to determine the levels of compounds contained in the $\mathrm{MnO}_{2}$ sample. XRD (x-ray diffraction) Shimadzu type 7000 analysis was also carried out to determine the polymorphy formed and SEM analysis to determine the polymorphy of $\mathrm{MnO}_{2}$ formed.

Manganese ore is obtained from Trenggalek. At first, manganese ore was analyzed using XRF to determine the elements contained in the ore, and the results of XRF testing are shown in Table 1. Manganese ore was then leached using the sulfuric acid solution at a stirring speed of 400 rpm, the acid concentration of $12 \% \quad \mathrm{H}_{2} \mathrm{SO}_{4}$, temperature $75{ }^{\circ} \mathrm{C}$ for 180 minutes to produce $\mathrm{MnSO}_{4}$ precursor solution which will be used as raw material for $\mathrm{MnO}_{2}$ synthesis.

Table 1. XRF analysis of manganese ore from Trenggalek[9]

\begin{tabular}{cc}
$\begin{array}{c}\text { Oxide } \\
\text { Compounds }\end{array}$ & Wt.\% \\
\hline $\mathrm{MnO}_{2}$ & 46.03 \\
$\mathrm{SiO}_{2}$ & 48.73 \\
$\mathrm{Fe}_{2} \mathrm{O}_{3}$ & 3.77 \\
$\mathrm{CaO}$ & 1.10 \\
$\mathrm{BaO}$ & 0.46 \\
$\mathrm{MgO}$ & 0.00 \\
$\mathrm{P}_{2} \mathrm{O}_{5}$ & 0.56 \\
\hline
\end{tabular}

\section{RESUltS AND DiscuSSIONS}

ICP-OES (inductively coupled plasmaoptical emission spectrometry) was used to determine the manganese content of the $\mathrm{MnSO}_{4}$ precursor solution during the initial characterization. Table 2 shows the results of the ICP-OES analysis of the $\mathrm{MnSO}_{4}$ solution, which shows that the manganese content in the precursor is around $387.185 \mathrm{ppm}$. 


\begin{tabular}{lc}
\hline \multicolumn{1}{c}{ Element } & ppm \\
\hline Aluminum $(\mathrm{Al})$ & 0.505078 \\
Gold $(\mathrm{Au})$ & 0.012406 \\
Boron $(\mathrm{B})$ & 0.085176 \\
Calcium $(\mathrm{Ca})$ & 4.18425 \\
Iron $(\mathrm{Fe})$ & 0.194278 \\
Potassium $(\mathrm{K})$ & 0.324122 \\
Lithium $(\mathrm{Li})$ & 0.0204 \\
Magnesium $(\mathrm{Mg})$ & 1.05311 \\
Manganese $(\mathrm{Mn})$ & 387.185 \\
Sodium $(\mathrm{Na})$ & 0.964326 \\
\hline
\end{tabular}

\subsection{Electrolysis Process}

Electrolysis is a decomposition reaction in an electrolyte by an electric current. When an electric current is passed through an electrolyte solution in an electrolytic cell, a chemical reaction occurs. [10].

The color change that occurs in the $\mathrm{MnSO}_{4}$ precursor during the electrolysis process is directly visible. The solution was pink before the electrolysis process was carried out, as shown in Fig.1(a), and after the electrolysis process was completed for 5 hours, the solution changed color to dark brown, as shown in Fig.1(b), where a very significant change in the color of the solution was obtained at an electrolyte temperature of $60{ }^{\circ} \mathrm{C}$ and a current of $5 \mathrm{~A}$.

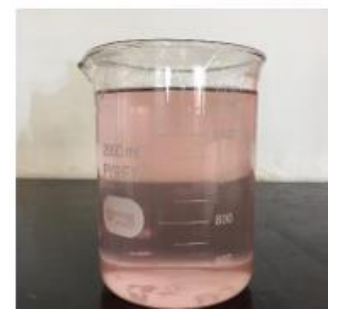

(a)

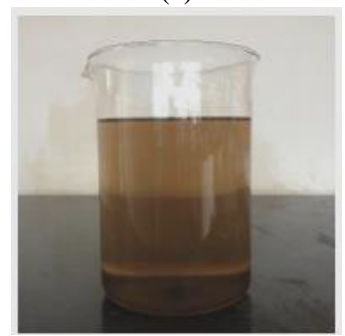

(b)

Figure 1. (a) Precursor solution before electrolysis process; (b) Precursor solution after electrolysis process

The $\mathrm{MnSO}_{4}$ solution will decompose into $\mathrm{Mn}^{2+}$ and $\mathrm{SO}_{4}{ }^{2-}$ ions during the electrolysis process. $\mathrm{Mn}^{2+}$ ions will flow to the anode, causing the reaction described in Eq. (1) to occur [11].

$\mathrm{Mn}^{2+}+2 \mathrm{H}_{2} \mathrm{O} \rightleftharpoons \mathrm{MnO}_{2}+4 \mathrm{H}^{+}+2 \mathrm{e}^{-}$

$\mathrm{MnO}_{2}+\mathrm{Mn}^{2+}+2 \mathrm{H}_{2} \mathrm{O} \rightleftharpoons 2 \mathrm{MnOOH}+2 \mathrm{H}^{+}$

$\mathrm{MnOOH} \rightleftharpoons \mathrm{MnO}_{2}+\mathrm{H}^{+}+\mathrm{e}^{-}$

Eq. 2 depicts the reaction that occurs at the cathode.
While Eq. 3 shows the total electrolysis reaction,

$$
\mathrm{MnSO}_{4}+2 \mathrm{H}_{2} \mathrm{O} \rightleftharpoons \mathrm{MnO}_{2}+\mathrm{H}_{2} \mathrm{SO}_{4}+\mathrm{H}_{2}
$$

\subsection{Electrolysis with Temperature Variation of the Electrolyte}

The electrolysis procedure was carried out with electrolyte temperatures ranging from 30 to 40,50 , and $60{ }^{\circ} \mathrm{C}$. According to the findings of the study, the lowest mass gain of $\mathrm{MnO}_{2}$ was obtained at $30{ }^{\circ} \mathrm{C}$, which was 2.98 grams, and the highest mass gain of $\mathrm{MnO}_{2}$ was obtained at $60{ }^{\circ} \mathrm{C}$, which was 11.4 grams.

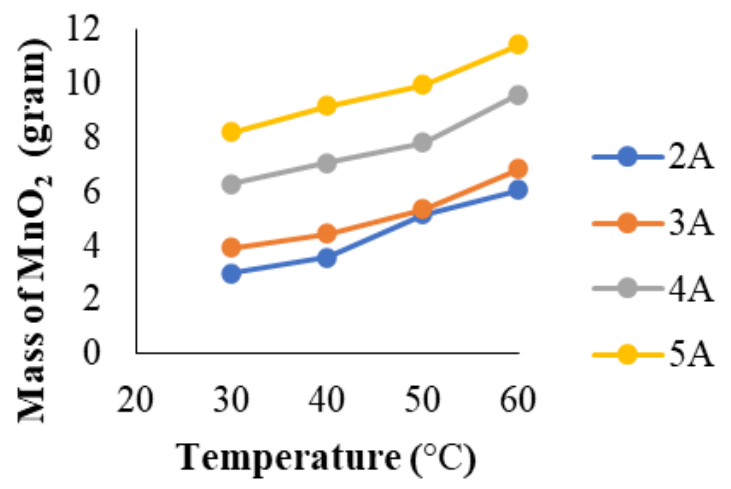

Figure 2. Effect of electrolyte temperature variations on mass gain of $\mathrm{MnO}_{2}$

The greater the mass of $\mathrm{MnO}_{2}$ obtained, the higher the temperature of the electrolyte used. Because the mass gain of $\mathrm{MnO}_{2}$ obtained was greater and the electrolyte temperature tended to be more constant at $60{ }^{\circ} \mathrm{C}$, the optimum condition of the electrolysis process was achieved.

\subsection{Electrolysis with Current Variation}

The current variations used were 2, 3, 4, and 5 A. According to the findings of the study, the lowest mass gain of $\mathrm{MnO}_{2}$ was obtained at $2 \mathrm{~A}$ current, which was 2.98 grams, and the highest $\mathrm{MnO}_{2}$ mass was obtained at $5 \mathrm{~A}$ current, which was 11.4 grams.

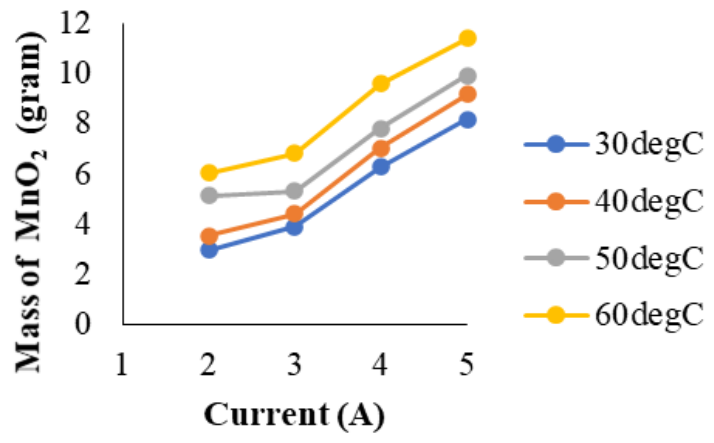

Figure 3. Effect of current variation on mass gain $\mathrm{MnO}_{2}$ 
The reaction rate of the electrolysis process can be affected by current. The higher the current user, the more $\mathrm{MnO}_{2}$ is formed.

\section{4 $\mathrm{MnO}_{2}$ XRF Analysis}

The levels of $\mathrm{MnO}_{2}$ formed after the electrolysis process were determined using XRF (x-ray fluorescence) analysis. Table 3 shows the XRF characterization results, which show $\mathrm{MnO}_{2}$ levels of $85.472 \mathrm{wt} . \%$.

Table 3. XRF analysis for $\mathrm{MnO}_{2}$

\begin{tabular}{cc}
\hline Compound & Wt.\% \\
\hline $\mathrm{K}_{2} \mathrm{O}$ & 0.066 \\
$\mathrm{MoO}_{3}$ & 0.019 \\
$\mathrm{TiO}_{2}$ & 0.044 \\
$\mathrm{MnO}_{2}$ & 85.472 \\
$\mathrm{Fe}_{2} \mathrm{O}_{3}$ & 2.128 \\
$\mathrm{SiO}_{2}$ & 8.377 \\
$\mathrm{~V}_{2} \mathrm{O}_{5}$ & 0.05 \\
$\mathrm{P}_{2} \mathrm{O}_{5}$ & 0 \\
$\mathrm{CaO}$ & 0.084 \\
$\mathrm{Cr}_{2} \mathrm{O}_{3}$ & 0.174 \\
$\mathrm{NiO}^{\mathrm{SO}}$ & 0 \\
$\mathrm{SO}_{3}$ & 3.574 \\
$\mathrm{Sc}_{2} \mathrm{O}_{3}$ & 0 \\
\hline
\end{tabular}

The increase in $\mathrm{MnO}_{2}$ levels after the electrolysis process was initially $46.03 \mathrm{wt} . \%$ and increased to $85.472 \mathrm{wt} . \%$. This indicates that the electrolysis process used can increase the levels of $\mathrm{MnO}_{2}$ formed. The higher purity of $\mathrm{MnO}_{2}$ obtained will improve $\mathrm{MnO}_{2}$ 's electrical performance as a lithium battery cathode even more.

\subsection{XRD Analysis on $\mathrm{MnO}_{2}$}

The polymorphy of the crystal structure formed in $\mathrm{MnO}_{2}$ compounds was also determined using XRD (x-ray diffraction). XRD analysis was performed on three samples, the lowest current of $2 \mathrm{~A}$ at a temperature of $60{ }^{\circ} \mathrm{C}$, the highest current of $5 \mathrm{~A}$ at a temperature of $30^{\circ} \mathrm{C}$, and the highest current of $5 \mathrm{~A}$ at a temperature of $60{ }^{\circ} \mathrm{C}$. Using the OriginPro 2021 software, the polymorphs in $\mathrm{MnO}_{2}$ compounds were identified by comparing the results of the sample $\mathrm{x}$-ray diffraction test with data from the ICDD (international center for diffraction data) standard. Figure 4 shows comparative images of $\mathrm{x}$-ray diffraction for each currency. The comparison image of the experimental $\mathrm{MnO}_{2}$ sample's x-ray diffraction pattern has similarities with the X-ray diffraction pattern based on ICDD standard No. 00-0440141 , which is a diffraction pattern of $\alpha-\mathrm{MnO}_{2}$ polymorphy with a tetragonal crystal system. The XRD test was performed with an angle of $2 \theta$ between $15^{\circ}$ and $90^{\circ}$. Typical peaks of $\alpha-\mathrm{MnO}_{2}$ were found at $2 \theta\left(^{\circ}\right)=26,29,37,42$, and 56 in sample $2 \mathrm{~A} ; 60{ }^{\circ} \mathrm{C}$, and impurity peaks were found at $2 \theta\left({ }^{\circ}\right)=24,27,32$, and 55. Typical peaks of $\alpha-\mathrm{MnO}_{2}$ were found at $2 \theta\left(^{\circ}\right)=18,26$, $29,36,37,46,47,49,52,56,57,60$, and 73 in sample $5 \mathrm{~A} ; 30{ }^{\circ} \mathrm{C}$, with impurity peaks found at $2 \theta\left(^{\circ}\right)=16,25,27,28,35,43$, and 55. Typical peaks of $\alpha-\mathrm{MnO}_{2}$ were found at $2 \theta\left(^{\circ}\right)=18,26$, $29,37,42,50$, and 57 in sample $5 \mathrm{~A} ; 60^{\circ} \mathrm{C}$, and impurity peaks were found at $2 \theta\left(^{\circ}\right)=27,35,38$, and 55 .

The sample contains approximately $82.7 \%$ $\alpha-\mathrm{MnO}_{2}$ compounds and $17.3 \%$ graphite, according to XRD analysis. The presence of other compounds in the $\mathrm{MnO}_{2}$ sample caused the formation of this impurity peak, with graphite containing the most impurity.

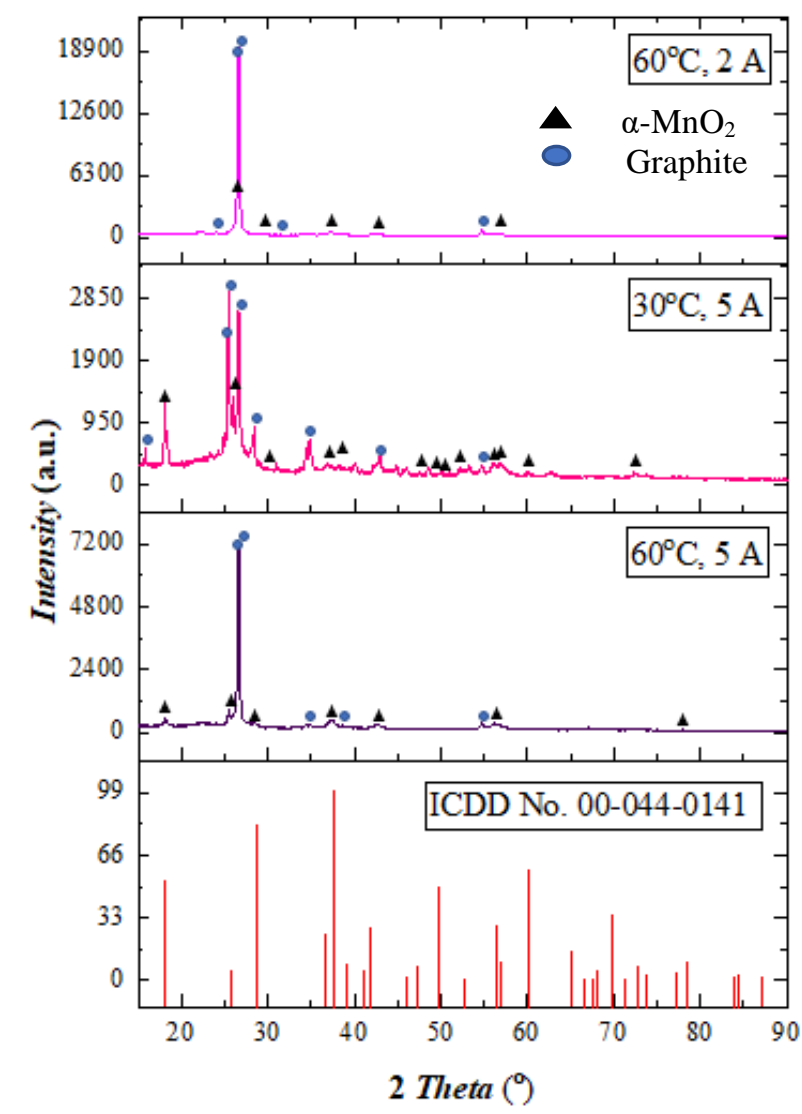

Figure 4. X-ray diffraction pattern for electrolyzed $\mathrm{MnO}_{2}$ based on ICDD No. 00-044-0141

The brittle nature of the graphite electrode can cause graphite impurities because graphite is easily eroded and mixed with $\mathrm{MnO}_{2}$. Based on the three XRD images obtained, it is possible to conclude that $\mathrm{MnO}_{2}$ compounds with $\alpha-\mathrm{MnO}_{2}$ structural polymorphy are obtained at each temperature and current used. Polymorphy with a 
$\alpha-\mathrm{MnO}_{2}$ structure is best suited for use as a battery cathode material [12]. Because it has a crystal structure large enough to accommodate and decompose oxygen molecules, the structure of $\alpha-\mathrm{MnO}_{2}$ has the best electrocatalytic ability [6].

\subsection{SEM Analysis on $\mathrm{MnO}_{2}$}

SEM (scanning electron microscope) analysis was also performed to determine the morphology of the $\mathrm{MnO}_{2}$ formed. At a temperature of $60{ }^{\circ} \mathrm{C}$ and a current of $5 \mathrm{~A}$, SEM analysis was performed on the sample with the highest mass gain of $\mathrm{MnO}_{2}$.

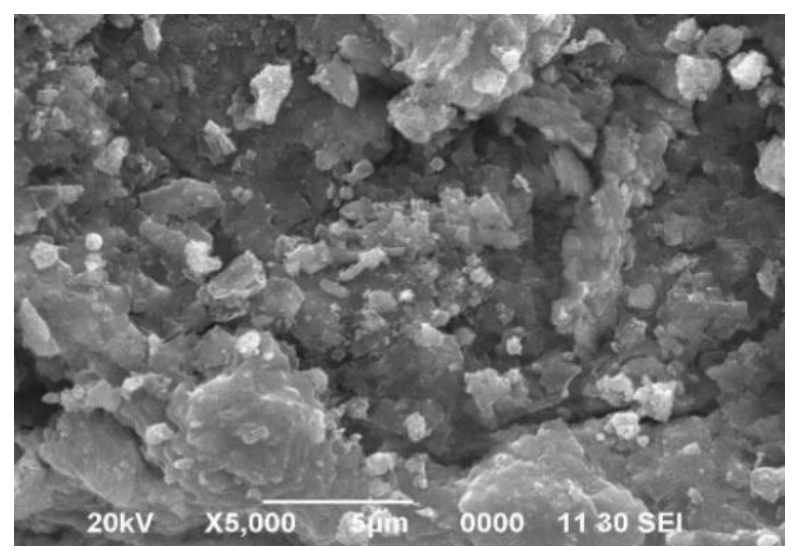

(a)

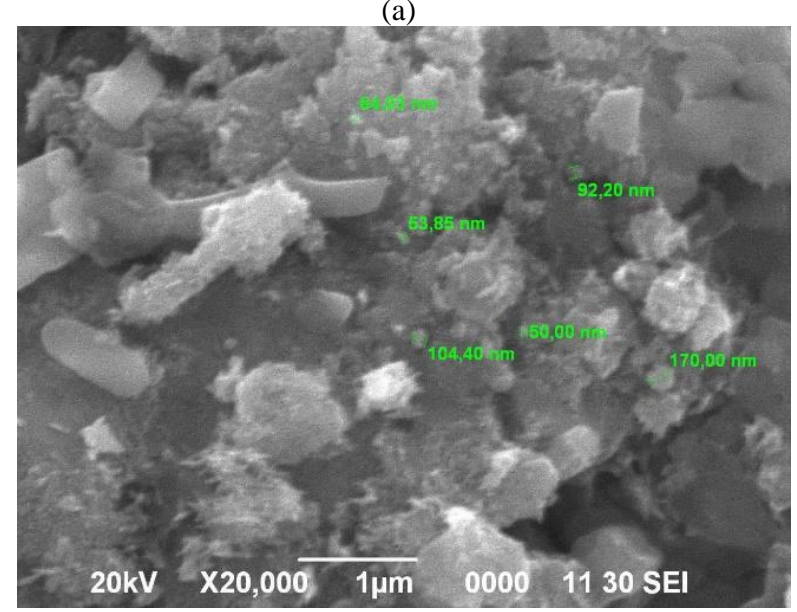

(b)

Figure 5. (a) Morphology of $\mathrm{MnO}_{2}$ using SEM at $60{ }^{\circ} \mathrm{C}$ and $5 \mathrm{~A}$ current, (b) Magnification of (a) which $\mathrm{MnO}_{2}$ diameter particle size

Figure 5 shows that the particle diameters of the $\mathrm{MnO}_{2}$ particles produced at a current of $5 \mathrm{~A}$ range from 50 to $170 \mathrm{~nm}$ at a magnification of $20,000 x$. The acquisition of a much smaller diameter of the $\mathrm{MnO}_{2}$ particle increases the surface area of the particle, allowing the $\mathrm{MnO}_{2}$ particle's electrical storage performance to improve.

\section{Conclusions}

The highest mass gain was obtained at the use of an electrolyte temperature of $60{ }^{\circ} \mathrm{C}$ and a current of $5 \mathrm{~A}$, which was 11.4 grams. The higher temperature of the electrolyte, the mass gain of $\mathrm{MnO}_{2}$ will increase, as well as the higher the current used, the mass gain of $\mathrm{MnO}_{2}$ will be increase. The brittle nature of the graphite electrode can cause graphite to be easily eroded and mixed with $\mathrm{MnO}_{2}$. The $\mathrm{MnO}_{2}$ compound has a spiny round shape and tends to agglomerate with particle diameter values ranging from 50$170 \mathrm{~nm}$.

\section{ACKNOWLEDGEMENT}

The authors would like to thank the staff and researchers at the Metallurgical and Materials Research Center LIPI (RCMM-LIPI) who have helped a lot in this research and this research was supported by the RCMM-LIPI.

\section{REFERENCES}

[1] A. Biswal, B. C. Tripathy, K. Sanjay, T. Subbaiah, and M. Minakshi, "Electrolytic manganese dioxide (EMD): A perspective on worldwide production, reserves and its role in electrochemistry," RSC Adv., vol. 5, no. 72 , pp. 58255-58283, 2015. Doi: $10.1039 / \mathrm{c} 5 \mathrm{ra} 05892 \mathrm{a}$

[2] Pusat Sumber Daya Geologi, "Pemutakhiran data dan neraca sumber daya mineral status 2015," pp. 1-25, 2015. http://psdg.geologi.esdm.go.id/Neraca/201 5/ (diunduh pada tanggal 13 November 2020 pukul $20.21 \mathrm{WIB}$ )

[3] B. R. A. Safitri, "Analisis kandungan mineral logam mangan (Mn) di kawasan pertambangan desa bangkang," Jurnal Ilmiah IKIP Mataram, vol. 2, no. 1, pp. 122-132, 2010.

[4] X. Huang, D. Lv, Q. Zhang, H. Chang, J. Gan, and Y. Yang, "Highly crystalline macroporous $\beta-\mathrm{MnO} 2$ : Hydrothermal synthesis and application in lithium battery," Electrochim. Acta, vol. 55, no. 17, pp. 4915-4920, 2010. Doi: 10.1016/j.electacta.2010.03.090

[5] M. Devenney, S. W. Donne, and S. Gorer, "Application of combinatorial methodologies to the synthesis and characterization of electrolytic manganese dioxide," J. Appl. Electrochem., vol. 34, no. 6, pp. 643-651, 2004. Doi: 10.1023/B:JACH.0000021915.73788.4c

[6] N. Saridewi, S. Arif, and A. Alif, "Sintesis nanomaterial mangan oksida dengan metode bebas pelarut," J. Kim. Val., vol. 1, no. November, pp. 117-123, 2015. Doi: $10.15408 / j k v . v 0 i 0.3147$

[7] V. P. Viscarini and N. U. R. Rokhima, 
"Sintesa partikel $\mathrm{MnO}_{2}$ dengan teknik elektrokimia dalam sel membran," Biomass Chem Eng, vol. 49, no. 23-6, pp. 1-15, 2015.

[8] G. K. Putri, "Sintesis $\mathrm{MnO}_{2}$ dengan metode elektrokimia sebagai elektrokatalis pada metal air battery," Diss. Institut Teknologi Sepuluh Nopember., vol. 9, no. 5. 2017.

[9] L. Andriyah dan E. Sulistiyono, "Proses pemurnian mangan sulfat dengan pengendapan selektif menggunakan karbon aktif dan larutan $\mathrm{NaOH}$," Technical Report, 2014.

[10] E. Marlina, S. Wahyudi, and L. Yulianti, "Produksi brown's gas hasil elektrolisis $\mathrm{H}_{2} \mathrm{O}$ dengan katalis $\mathrm{NaHCO}_{3}$," Jurnal Rekayasa Mesin, vol. 4, no. 1, pp. 53-58, 2013.

[11] L. M. Kwon, J. W. Kim, U. U. Chi and J. J. Shin "A study on the preparation of electrolytic manganese dioxide," Journal of the Korean Chemical Society, vol. 17, no. 4, pp. 306-313, 1973.

[12] K. Song, J. Jung, Y. U. Heo, Y. C. Lee, K. Cho, and Y. M. Kang, " $\alpha-\mathrm{MnO}_{2}$ nanowire catalysts with ultra-high capacity and extremely low overpotential in lithium-air batteries through tailored surface arrangement," Phys. Chem. Chem. Phys., vol. 15, no. 46, pp. 20075-20079, 2013. Doi: $10.1039 / \mathrm{c} 3 \mathrm{cp} 53754 \mathrm{~d}$ 